\title{
THE INFLUENCE OF CONSUMER LIFESTYLE IN THE REPUBLIC OF SERBIA ON CONSUMER ETHNOCENTRISM
}

\author{
Dragana Gašević* \\ Novi Sad School of Business, Novi Sad, Republic of Serbia \\ Marija Vranješ \\ Novi Sad School of Business, Novi Sad, Republic of Serbia \\ Dragana Tomašević \\ Novi Sad School of Business, Novi Sad, Republic of Serbia
}

\begin{abstract}
Consumer behavior is determined by a number of factors. One of them is ethnocentric tendencies. Ethnocentric consumers are those who prefer to buy domestic products rather than products of foreign origin. As not all consumers are equally ethnocentric, the main objective of the paper is to identify the individual and cumulative impact of certain components of respondents' lifestyle on consumer ethnocentrism. The results have shown a statistically significant influence of three dimensions of lifestyle (personality traits, practical and rational purchasing behavior and fashion awareness) on consumer ethnocentrism of respondents in the Republic of Serbia. The analysis of the gathered data was performed using factor analysis and regression analysis. The research results have provided a great deal of meaningful information necessary for strategic management and decision making. In addition, the base for devising better quality strategies for approaching individual groups of consumers is provided, all depending on the degree of their consumer ethnocentrism.
\end{abstract}

Key words: consumer ethnocentrism, lifestyle, consumer behavior

JEL Classification: M31, C38

\footnotetext{
*draganag.vps@gmail.com
} 


\title{
UTICAJ ŽIVOTNOG STILA POTROŠAČA U REPUBLICI SRBIJI NA POTROŠAČKI ETNOCENTRIZAM
}

\begin{abstract}
Sažetak: Ponašanje potrošača determinisano je velikim brojem faktora. Jedan od njih su i etnocentrične tendencije. Etnocentrični potrošači su oni koji radije kupuju domaće proizvode nego proizvode stranog porekla. Kako nisu svi potrošači podjednako etnocentrični, osnovni cilj rada je da se identifikuje pojedinačni i kumulativni uticaj pojedinih komponenti životnog stila ispitanika na potrošački etnocentrizam. Rezultati su pokazali statistički značajan uticaj tri dimenzije životnog stila (karakteristike ličnosti, praktično i racionalno ponašanje prilikom kupovine i modna osvešćenost) na potrošački etnocentrizam ispitanika u Republici Srbiji. Analiza prikupljenih podataka obavljena je primenom faktorske $i$ regresione analize. Rezultati istraživanja pružaju veliki broj značajnih informacija neophodnih za strateško upravljanje i odlučivanje. Pored toga, obezbeđena je i osnova za kreiranje kvalitetnijih strategija nastupa prema pojedinim grupama potrǒ̌ača, a sve u zavisnosti od stepena njihovog potrošačkog etnocentrizma.
\end{abstract}

Ključne reči: potrošač, potrošački etnocentrizam, ponašanje potrošača, životni stil

\section{INTRODUCTION}

In today's business environment, international trade volume is increasing exponentially, and consumers in most countries today are exposed to a wide range of products coming from all around the world (Pentz, Terblanche and Boshoff, 2014). Due to a number of factors that determine their attitudes and intentions in the purchasing process, consumers should be seen as a very important resource (Gašević, Jovičić, Tomašević and Vranješ, 2017). Consumer behavior and purchasing decisions, among other factors, can be influenced by the origin of the product. In this regard, many marketers suggest that a better understanding of consumer behavior towards both domestic and imported products could be of great importance in formulating more effective marketing strategies. Martínez, Barrio-García and Ibáñez-Zapata (2000) emphasize that consumer ethnocentrism research can be an important step towards a better understanding of how individuals compare domestic with foreign products, as well as the reasons that may lead them to develop patriotic prejudices about imported products.

Consumer ethnocentrism is a kind of behavior that implies giving priority to buying domestic over foreign products (Gašević et al., 2017). Previous research in the field of international marketing suggests that the concept of consumer ethnocentrism can be a very important factor when consumers decide to buy 
80 | THE INFLUENCE OF CONSUMER LIFESTYLE IN THE REPUBLIC OF SERBIA ON CONSUMER ETHNOCENTRISM

locally produced rather than imported products. Research into this phenomenon was previously restricted to developed countries only. In developed economies, consumers generally take pride in their domestic products and favor them over foreign products (Klein, Balaji and Ettenson, 2006). However, in recent years, research in the markets of developing countries has also been conducted (Pentz et al., 2014). For example, in some transition economies, domestic products are seen as less desirable than imported ones. Decades of buying "bad" products originating from "state-owned factories" in Russia and China have led consumers in those countries to rate foreign products more positively than those produced in their home country (Klein et al., 2006). Although incorporating demographic characteristics into consumer behavior studies increases their managerial relevance (Homburg and Giering, 2001), some authors find that demographic and socioeconomic data are not "rich enough" and often need to be supplemented with additional data (Wells, 1975). As consumer ethnocentrism and consumer lifestyles are among the main influences on purchasing behavior (Acikdilli, Ziemnowicz and Bahhouth, 2018), this empirical study will explore the impact of individual consumer lifestyle dimensions on consumer ethnocentrism. Most of previous research analyzing consumer lifestyles was conducted in Western countries. The basis of this research is a lifestyle analysis aimed at identifying segments of consumers who share similar patterns of social beliefs and behavior. In fact, the authors will apply a model used to investigate the same issues by observing consumer behavior in Turkey.

\section{THEORETICAL BACKGOUND}

Lifestyle is simply defined as "how one lives". According to some authors, lifestyle refers to the economic status of people, then how they spend their money and how they allocate their time (Anderson and Golden, 1984). Consumer lifestyles function like the syndrome of interconnected personality traits, attitudes and values, and have a relatively higher predictive value in assessing consumer behavior than other consumer characteristics (Slišković, Zebić, Gregov and Nikolić, 2014). Research into consumer lifestyles and consumer ethnocentrism is a unique way of detecting consumer behavior (Kucukemiroglu, Harcar and Spillan, 2006). The basic premise of lifestyle research is that the more marketers know and understand consumers, the more effectively they can interact with and serve them (Kaynak and Kara, 1996). The focus of marketers and consumer researchers has largely been on identifying trends that affect the life and work of consumers. Therefore, lifestyle patterns give a broader, three-dimensional view of consumers, and thus marketers can manage consumer relationships more intelligently. 
The most commonly used lifestyle measurement approach is the evaluation of Activities, Interests, Opinions - AIO statements (Wells and Tigert, 1977). The measurement of activities, interests, and opinions applied in this empirical study was used in the analysis to identify how consumer lifestyle components influence their purchase decision. The general definition of consumer ethnocentrism is related to the phenomenon whereby consumers prefer domestic products or have a bias towards imported ones (LeVine and Campbell, 1972). Research have shown that among Korean consumers, ethnocentric tendencies play a more important role when making product purchasing decisions, which is an important source of employment and income for the domestic economy (Sharma, Shimp and Shin, 1995). Also, non-ethnocentric consumers in Turkey tend to express significantly more favorable beliefs, attitudes and intentions regarding imported products than ethnocentric consumers do (Kucukemiroglu, 1999). Namely, when the imported product is perceived as less needed, ethnocentric tendencies can play a more important role in purchase decisions (Kucukemiroglu, 1999).

Subsequent analysis of ethnocentric consumer behavior in Turkey have shown that Turkish consumers are quite rational and do not discriminate against imported products, but have preferences for local products that are of equal quality to imported ones, because their purchases stimulate the economic development of the country, boosting the employment of the nation (Acikdilli et.al., 2018). Research results obtained on a sample of 602 consumers in 2012 in Chile have shown that the degree of consumer ethnocentrism varies due to differences in respondents' demographics (Rojas-Mendes, Chaubey and Spillan, 2013). Related to these are the results of research in Chinese society (Hsu and Nien, 2008) showing that ethnocentric consumers in two Chinese cities (Shanghai and Taipei) are relatively older, possess a lower level of education, and travele less abroad during the last three years. Interestingly, respondents from Shanghai have shown a higher degree of consumer ethnocentrism than respondents from Taipei. The attitudes of ethnocentric consumers towards different product categories are also different. Respondents from Shanghai consider domestic mobile phone brands to be the best choice, while respondents in Taipei ranked domestic mobile phone brands in second place.

When it comes to investigating this concept among consumers in France and the effects on attitudes towards imports and then on purchase intentions, interesting results have been obtained. Namely, the French, who are not overly ethnocentric, are willing to buy products from other countries, but they are likely to buy certain products only because of the brand and reputation of those products. French consumers show an inclination for German cars, as well as American and Japanese computers. In addition, product necessity was found to have a significant effect on the link between ethnocentrism and the relationship 
82 I THE INFLUENCE OF CONSUMER LIFESTYLE IN THE REPUBLIC OF SERBIA ON CONSUMER ETHNOCENTRISM

to foreign product imports. This means that ethnocentric consumers may have a more positive attitude towards purchasing imported products that they consider necessary, as opposed to unnecessary products, such as luxury items (Javalgi, Gross, Khare and Scherer, 2005). The reserch conducted on a sample of 304 respondents in Estonia in 2015, regarding the impact of consumer ethnocentrism on the purchase of products belonging to the skin care category, have found out that consumers tend to buy foreign products for this purpose. Surveyed consumers do not think that buying locally produced products is important, nor that buying foreign products is wrong or irresponsible. However, consumers who express high levels of ethnocentrism still prefer to purchase home-made skin care products (Garmatjuka and Partsb, 2015).

Results of consumer studies in Russia (100 students and 100 non-student respondents) and consumers in China (115 students and 116 non-student respondents) have shown that consumers in these transition economies consider the quality of domestic products to be lower than the quality of foreign products. In a survey investigating attitude toward products from four specific countries (USA, Korea, Japan and Hungary), the results have shown that only Russian students have a negative attitude towards products from Hungary (Klein et al., 2006).

\section{RESEARCH METHODOLOGY}

This paper came as a result of a survey conducted in the period from April to June in 2016, on a random sample of respondents. The survey method was used for collecting research data, i.e. a questionnaire was devised and filled in by the respondents electronically. The questionnaire consisted of three parts. The first part addressed the demographic and socioeconomic characteristics of the respondents. The second part contained an adapted AIO model that included 21 statements and was a modified version of a questionnaire that had been formulated and applied for the purpose of identifying the lifestyle of Turkish consumers and actually contained 56. A five-point Likert scale was used in which 1 meant I strongly disagree, and 5 standed for I strongly agree. An earlier analysis of the reliability of the statements that make up the above model shown that the value of Cronbach's Alpha coefficient was 0.73 which is satisfactory. Also, the analysis of the reliability of the AIO model containing 56 statements shown that the value of Cronbach's alpha coefficient was 0.92 , which can be considered a satisfactory value (Kucukemiroglu, 1999). The third part of the questionnaire was CETSCALE created by Shimp and Sharma (1987) with 17 statements. CETSCALE was used to detect the tendency of consumers to prefer domestically made products as opposed to ones with foreign origin (Acikdilli et.al., 2018). Respondents were also asked to expressed their degree of 

agreement with the statements in this set of questions via the five-point Likert scale. The five-point Likert scale was also applied in papers that explored the same topic in Malaysia, Ethiopia, and Nigeria (Teo, Mohamad and Ramayah, 2011; Mangnale, Poturi and Defgfu, 2011; Chendo, 2013). Getting accurate information from the market depends heavily on using valid and reliable scales. Numerous studies have confirmed the validity and reliability of the standard measurement instrument of consumer ethnocentrism (CETSCALE). Data collected from 278 students in Iran during 2012 were used to examine the onedimensionality, internal consistency, discriminatory and nomological validity of CETSCALE. The results validated the unidimensionality of the scale, however, due to bad model customization, a much "simpler" scale was developed, removing 7 items. The reliability and discriminant validity of CETSCALE was strongly supported by the data, although support for nomological validity was not strong (Sepehr and Kaffashpoor, 2012). Then, the value of Cronbach's Alpha coefficient on the sample of Turkish respondents was 0.88 , which is also a reasonably high reliability coefficient (Kucukemiroglu, 1999). In addition, the validity of the concept of consumer ethnocentrism in the case of consumers in Bosnia and Herzegovina was proven by the high reliability of CETSCALE, with a Cronbach's Alpha coefficient value of 0.95 (Čutura, 2006). Also, a study of consumer ethnocentrism in the Australian market using an adapted version of a consumer ethnocentrism scale containing six statements shown good reliability of the scale with a value of 0.86 (Josiassen, Assaf and Karpen, 2011). The internal consistency and reliability of the consumer ethnocentrism scale used in this study was satisfactory since it was 0.95. Acceptable values of this coefficient are those above 0.7, while desirable values are above 0.8 (Pallant, 2011). During the research period, data were collected from 168 subjects. The sample was female-dominated $(66.5 \%)$, while the largest number of respondents belonged to the age category from 29 to 48 years $(54.8 \%)$. Furthermore, the majority of respondents had completed high school (44\%) and earned incomes of up to 25,000 dinars $(32,1 \%)$. The collected data were saved and analyzed in the SPSS (Statistical Package for the Social Science for Windows, version 19.0) software package. Originally, factor analysis was applied, which represents one of the most popular multivariate techniques for reducing a large number of variables to a smaller number of factors. The application of this technique resulted in the separation of four factors. Thereafter, regression analysis was applied to determine whether there was a linear relationship between the obtained factors (viewed as independent variables) and the dependent variable (consumer ethnocentrism). 


\section{RESEARCH RESULTS}

Pallant (2011) points out that factor analysis is a technique for reducing the amount of data. It is applied in situations where the goal is to reduce a large number of characteristics (source variables) to a smaller number of factors that will describe them and explain their interrelation (Kurnoga Živadinović, 2004). In the first step of this research, specific assumptions, that must be previously satisfied in order for factor analysis to be applied, were tested. Since the variables measured on the interval scale were selected, it was concluded that the first assumption was satisfied. Since the number of variables was 21 and the sample size was 168 , it could be concluded that the second assumption about the ratio of the number of observations (sample size) and the number of variables that need to be analyzed was fulfilled. Barttlett's test of sphericity and Kaiser-Meyer Olkin's sample adequacy test were used to verify the third assumption, that is, to analyze the feasibility of applying the factor analysis. Anti - image correlation was also applied. The results of the application of this matrix shown that four variables had not meet the criteria for being included in the factor analysis and were eliminated from the model (Appendix 2). The KMO test for the remaining 17 variables that had met the criteria of the Anti image matrix was 0.762, which is greater than 0.6, while the Bartlett test of sphericity was statistically significant $(\mathrm{p}<0.05)$ (Table 5). Examination of the correlation matrix (Appendix 3) revealed a lot of correlation coefficients of 0.3 and above. The above results suggested that this assumption was also confirmed, that is, the remaining data were suitable for the application of factor analysis. In the following, the results will be presented indicating that the fourth assumption was satisfied, that is, there was no problem of multicollinearity (Table 6).

Table 1

Kaiser - Meyer - Olkin Test for Sampling Adequacy

\begin{tabular}{lc}
\hline Kaiser - Meyer Olkin Measure of Sampling Adequacy & 0.762 \\
Bartlett's Test of Sphericity (Approx. Chi-Square) & 1735.823 \\
df & 136 \\
Sig. & 0.000 \\
\hline
\end{tabular}

Note. Calculated by the authors.

Below is a definition of the Principal components analysis (PCA) that was applied to extract the factors for further analysis. The number of major components was determined using two criteria: the criterion based on characteristic values (Kaiser's criterion) and the criterion based on scree plot. The results showed that there were four factors with characteristic values above 
Dragana Gašević, Marija Vranješ, Dragana Tomašević | 85 1, which explained $23.36 \%, 19.75 \%, 17.01 \%$ and 10.58 of variance. That is, these factors explained a total of $70.72 \%$ of the variance of the dependent variable (Table 2). The aforementioned study of the impact of lifestyle on consumer behavior in Turkey resulted in 8 factors explaining $68.55 \%$ of the total variance (Kucukemiroglu, 1999).

Table 2

\section{Total Variance Explained}

\begin{tabular}{|c|c|c|c|c|c|c|c|c|c|}
\hline \multirow[b]{2}{*}{ 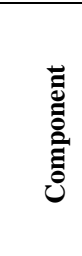 } & \multicolumn{3}{|c|}{ Initial Eigenvalues } & \multicolumn{3}{|c|}{$\begin{array}{c}\text { Extraction Sums of Squared } \\
\text { Loadings }\end{array}$} & \multicolumn{3}{|c|}{$\begin{array}{c}\text { Rotation Sums of Squared } \\
\text { Loadings }\end{array}$} \\
\hline & $\sqrt{5}$ & 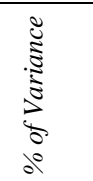 & 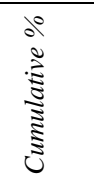 & $\frac{\sqrt{3}}{\tilde{3}}$ & 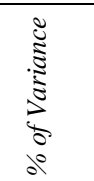 & 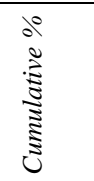 & $\frac{\sqrt{2}}{\sqrt[3]{\pi}}$ & 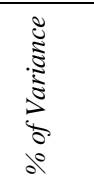 & 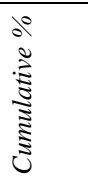 \\
\hline 1 & 3.972 & 23.364 & 23.364 & 3.972 & 23.364 & 23.364 & 3.701 & 21.772 & 21.772 \\
\hline 2 & 3.35 & & & & & & & & 39.010 \\
\hline 3 & & & & & & & & & 56.079 \\
\hline 4 & 1.799 & 10.582 & 70.720 & 1.799 & 10.582 & 70.720 & 2.489 & 14.641 & 70.720 \\
\hline
\end{tabular}

Note. Extraction Method: Principal Componenet Analsis.

Calculated by the authors.

For ease of interpretation, the factors were rotated using the Varimax method. In the further analysis, it was chosen to display those factor weights greater than 0.3. After factor rotation, such a factor matrix (Table 3) was obtained, where high values of factor weights (factor loadings) associated with only a small number of variables could be clearly distinguished for each factor.

The results in Table 3 show that the first factor comprises four statements with high factor loadings (over 0.90). This factor can be called the family concern factor and includes the following statements: „My children are the most important things in my life $(0,960)$ ”, „I take a lot of time and effort to teach my children good habits $(0,938)$ “, „When my children are ill in bed I drop most everything else in order to see to their comfort $(0,926)$ “ and „I try to arrange my home for my childrens convenience $(0,921)$ “. Also, the second factor includes four variables with factor loadings over 0.80 . This factor can be called practical and rational purchasing behavior and is accompanied by the following statements: „A person can save a lot of money by shopping around for bargains $(0,862)$ “, „I usually watch the advertisements for announcements of sales $(0,825)$ “, „I find myself checking the prices in the grocery store even for small

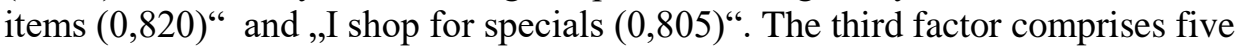
statements with factor loadings over 0.60 . This factor may be called personality traits. The statements associated with this factor are: „I think I have a lot of personal ability $(0,841)$ “, „I am more independent than most people $(0,830)$ “, ,I

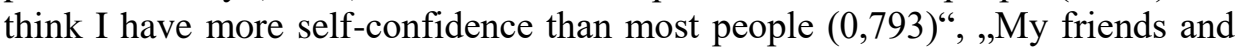


86 | THE INFLUENCE OF CONSUMER LIFESTYLE IN THE REPUBLIC OF SERBIA ON CONSUMER ETHNOCENTRISM

neighborsoften come to me for advice $(0,634)$ “ and „I like to be considered a leader $(0,606)$ “.

Finally, the fourth factor can be called fashion awareness. This factor includes four statements with factor loadings over 0.60: „I spend a lot of time talking with my friends about product and brands $(0,794)$ ”, „An important part of my life and activities is dressing smartly $(0,788)^{\text {“, }, ~ „ I ~ o f t e n ~ t r y ~ n e w ~ s t o r e s ~ b e f o r e ~ m y ~}$ friends and neighbors do $(0,768)$ “ and „I usually have one or more outfits that are the very latest style $(0,632)^{\text {“. }}$. All statements related to the above factors (family concern, practical and rational purchasing behavior, personality traits and fashion awareness) were also identically included in factors of the same names in the survey of Turkish respondents' lifestyle (Kucukemiroglu, 1999). Table 3 also contains data on the variance proportions of certain variables attributed to the effect of a given factor. The first factor explains the $92,16 \%$ variance of the variable „My children are the most important things in my life ”, then $87,98 \%$ variance of the variable „I take a lot of time and effort to teach my children good habits", then $85,74 \%$ variance of the variable "When my children are ill in bed I drop most everything else in order to see to their comfort" and $84,82 \%$ variance of the variable "I try to arrange my home for my childrens convenience". The second factor explains $74,30 \%$ variance of the variable „A person can save a lot of money by shopping around for bargains", 68,06\% variance of the variable „I usually watch the advertisements for announcements of sales“, $67,24 \%$ variance of the variable „I find myself checking the prices in the grocery store even for small items " and $64,80 \%$ variance of the variable „I shop for specials". The third factor explains: $70,72 \%$ variance of the variable „I think I have a lot of personal ability”, 68,89\% variance of the variable „I am more independent than most people“, $62,88 \%$ variance of the variable „I think I have more self-confidence than most people", $40,19 \%$ variance of the variable „My friends and neighbors often come to me for advice“ and 36,72\% variance of the variable „I like to be considered a leader“. The fourth factor explains o: $63,04 \%$ variance of the variable „I spend a lot of time talking with my friends about product and brands”, 62,09\% variance of the variable „An important part of my life and activities is dressing smartly”, 58,98\% variance of the variable „I often try new stores before my friends and neighbors do" and 39,94\% variance of the variable „I usually have one or more outfits that are the very latest style”. The results of applied factor analysis in previous studies have singled out four interpretable latent factors, that is, four different orientations of lifestyles of the examined consumer sample. Given the content of the statements grouped under a particular factor, the factors relate to innovative, family, social and leadership orientation. 
Table 3

Rotated Component Matrix

\begin{tabular}{|c|c|c|c|c|c|c|c|c|}
\hline & \multicolumn{4}{|c|}{ Component } & \multicolumn{4}{|c|}{ Square of factor loadings (\%) } \\
\hline & 1 & 2 & 3 & 4 & 1 & 2 & 3 & 4 \\
\hline $\begin{array}{l}\text { My children are the most } \\
\text { important things in my life. }\end{array}$ & ,960 & & & & 92,16 & & & \\
\hline $\begin{array}{l}\text { I take a lot of time and effort } \\
\text { to teach my children good } \\
\text { habits. }\end{array}$ & ,938 & & & & 87,98 & & & \\
\hline $\begin{array}{l}\text { When my children are ill in } \\
\text { bed I drop most everything } \\
\text { else in order to see to their } \\
\text { comfort. }\end{array}$ & ,926 & & & & 85,74 & & & \\
\hline $\begin{array}{l}\text { I try to arrange my home for } \\
\text { my childrens convenience. }\end{array}$ & 921 & & & & 84,82 & & & \\
\hline $\begin{array}{l}\text { A person can save a lot of } \\
\text { money by shopping around for } \\
\text { bargains. }\end{array}$ & &, 862 & & & & 74,30 & & \\
\hline $\begin{array}{ll}\text { I usually watch the } \\
\text { advertisements } & \text { for } \\
\text { announcements of sales. } & \end{array}$ & & ,825 & & & & 68,06 & & \\
\hline $\begin{array}{l}\text { I find myself checking the } \\
\text { prices in the grocery store } \\
\text { even for small items. }\end{array}$ & & 820 & & & & 67,24 & & \\
\hline I shop for specials. & & ,805 & & & & 64,80 & & \\
\hline $\begin{array}{l}\text { I think I have a lot of personal } \\
\text { ability. }\end{array}$ & & & ,841 & & & & 70,72 & \\
\hline $\begin{array}{l}\text { I am more independent than } \\
\text { most people. }\end{array}$ & & &, 830 & & & & 68,89 & \\
\hline $\begin{array}{l}\text { I think I have more self- } \\
\text { confidence than most people. }\end{array}$ & & & ,793 & & & & 62,88 & \\
\hline $\begin{array}{l}\text { My friends and } \\
\text { neighborsoften come to me for } \\
\text { advice. }\end{array}$ & & & ,634 & & & & 40,19 & \\
\hline $\begin{array}{l}\text { I like to be considered a } \\
\text { leader.. }\end{array}$ & & & 606 & & & & 36,72 & \\
\hline $\begin{array}{l}\text { I spend a lot of time talking } \\
\text { with my friends about product } \\
\text { and brands. }\end{array}$ & & & & ,794 & & & & 63,04 \\
\hline $\begin{array}{l}\text { An important part of my life } \\
\text { and activities is dressing } \\
\text { smartly. }\end{array}$ & & & & ,788 & & & & 62,09 \\
\hline $\begin{array}{l}\text { I often try new stores before } \\
\text { my friends and neighbors do. }\end{array}$ & & & & ,768 & & & & 58,98 \\
\hline $\begin{array}{l}\text { I usually have one or more } \\
\text { outfits that are the very latest } \\
\text { style. }\end{array}$ & & & &, 632 & & & & 39,94 \\
\hline
\end{tabular}

Extraction Method: Principal Component Analysis. Rotation Method: Varimax with Kaiser Normalization.

a. Rotation converged in 5 iterations. 
88 | THE INFLUENCE OF CONSUMER LIFESTYLE IN THE REPUBLIC OF SERBIA ON CONSUMER ETHNOCENTRISM

For example, within the factor labeled Innovative Orientation there is the statement "I usually go to newly opened shops before my friends and neighbors". The content of the statements that make up this factor is relatively identical with the factor that is marked as fashion awareness in fashion related research. Another factor, called family orientation, contains statements that match the family concern factor, such as "I spend a lot of effort and time teaching my children good habits." Under the third factor, described as social orientation, there are statements that were not analyzed in a specific survey in which a modified questionnaire was applied. The fourth factor, called leadership orientation, contains, for example, the statement "I think I am a very capable person" and is quite similar to the factor relating to personality traits. The reliability and internal consistency of all the above factors, as measured by the Cronbach Alpha coefficient, was satisfactory and the specific values were 0.77; $0.73 ; 0.71$ and 0.73 respectively (Slišković et al., 2014). Also, the results of applying factor analysis have indicated that there are nine major lifestyles among respondents in Chile (Rojas-Mendes et al., 2013). In addition, data collected in personal interviews in two cities in Vietnam have indicated that ten lifestyles among Vietnamese consumers influenced their ethnocentric tendencies and purchasing behavior (Kucukemiroglu et al., 2006), while data and results from two cities in Peru have shown that there are nine lifestyles among Peruvian consumers that influence their ethnocentric tendencies (Spillan, Mayolo and Kucukemiroglu, 2007). An analysis comparing the lifestyles of female consumers in Hong Kong, Taiwan and China have found out that there are significant differences in the sample across nine different areas: family orientation, cleanliness at home, brand awareness, price awareness, confidence, dependence on jobs, health and environmental awareness. Nevertheless, Tai and Tam (1998) predicted that the lifestyles of female consumers in China would become very similar to each other in the near future. The results of the regression analysis are presented below, where factors that emerged as a result of factor analysis appeared as independent variables, while the dependent variable was represented by consumer ethnocentrism. The calculated values of the coefficient of determination are presented in Table 4 . As $R^{2}=0.108$, it was concluded that $10.8 \%$ of the variability of the dependent variable hd been explained by the factors specified by factor analysis. In Table 5, the ANOVA value of Sig. $<0.05$ suggests that this result was statistically significant. Table 4 also shows the result of autocorrelation testing using Durbin-Watson statistics. As the value DW $=2.097$ was obtained, it was concluded that there was no auto correlation problem. 
Table 4

Model Summary

\begin{tabular}{lccccc}
\hline Model & $\mathbf{R}$ & R Square & $\begin{array}{c}\text { Adjusted R } \\
\text { Square }\end{array}$ & $\begin{array}{c}\text { Std. Error of the } \\
\text { Estimate }\end{array}$ & $\begin{array}{c}\text { Durbin- } \\
\text { Watson }\end{array}$ \\
\hline 1 & $.328^{\text {a }}$ & .108 & .086 & .90992 & 2.097 \\
\hline a. Predictors: & (Constant), REGR factor score 4 for analysis 2, REGR factor score 3 \\
for analysis 2, REGR factor score 2 for analysis 2, REGR factor score 1 for analysis 2 \\
d. Dependent Variable: Consumer ethnocentrism
\end{tabular}

Note. Calculated by the authors.

Table 5 shows the results of the analysis of variance ANOVA. Based on the value of Snedecor's $F$ statistics $(F=4.917)$ and the realized significance level ( $p$ $=0.001)$, it could be concluded that the coefficient of determination was different from zero and that the regression of the influence of the first, second, third and fourth factor variables on the level of consumer ethnocentrism was statistically significant.

Table 5

ANOVA

\begin{tabular}{|c|c|c|c|c|c|c|}
\hline & Model & Sum of Squares & df & Mean Square & $\mathbf{F}$ & Sig. \\
\hline \multirow[t]{2}{*}{1} & Regression & 16.286 & 4 & 4.071 & 4.917 & $.001^{\mathrm{a}}$ \\
\hline & Residual & 134.958 & 163 & .828 & & \\
\hline & Total & 151.244 & 167 & & & \\
\hline
\end{tabular}

Note. Calculated by the authros.

In order to identify how much each of the four independent variables contributed to the prediction of the dependent variable, the results from Table 6 should be looked at. It is evident that the variable under ordinal number 3 (personality traits) contributes most to the prediction of the dependent variable. Also the variable under number 2 (practical and rational purchasing behavior) and the variable under number 4 (fashion awareness) make a statistically unique contribution to explaining the variable consumer ethnocentrism. The impact of the family concern variable was not statistically significant.

When it comes to assumptions underlying multiple regression, the results of multicollinearity testing are also reported. If independent variables are highly correlated (when the values of the VIF factor are greater than 10), then the problem of multicollinearity arises. Based on Table 6 , it could be concluded that 
90 | THE INFLUENCE OF CONSUMER LIFESTYLE IN THE REPUBLIC OF SERBIA ON CONSUMER ETHNOCENTRISM

in this study the assumption was not violated because values of VIF factor for all four independent variables was 1 .

Table 6

Coefficients $^{\mathrm{a}}$

\begin{tabular}{|c|c|c|c|c|c|c|c|}
\hline \multirow[t]{2}{*}{ Model } & \multicolumn{2}{|c|}{$\begin{array}{c}\text { Unstandardized } \\
\text { Coefficients }\end{array}$} & \multirow{2}{*}{$\begin{array}{c}\begin{array}{c}\text { Standardized } \\
\text { Coefficients }\end{array} \\
\text { Beta }\end{array}$} & \multirow[t]{2}{*}{$\mathbf{t}$} & \multirow[t]{2}{*}{ Sig. } & \multicolumn{2}{|c|}{$\begin{array}{l}\text { Collinearity } \\
\text { Statistics }\end{array}$} \\
\hline & $B$ & Std. Error & & & & Tolerance & $V I F$ \\
\hline 1 (Constant) & 3.366 & .070 & & 49.951 & .000 & & \\
\hline $\begin{array}{l}\text { REGR factor } \\
\text { score } 1 \text { for } \\
\text { analysis } 2\end{array}$ & .084 & .070 & .089 & 1.199 & .232 & 1.000 & 1.000 \\
\hline $\begin{array}{l}\text { REGR factor } \\
\text { score } 2 \text { for } \\
\text { analysis } 2\end{array}$ & .176 & .070 & .184 & 2.493 & .014 & 1.000 & 1.000 \\
\hline $\begin{array}{l}\text { REGR factor } \\
\text { score } 3 \text { for } \\
\text { analysis } 2\end{array}$ & .195 & .070 & .204 & 2.763 & .006 & 1.000 & 1.000 \\
\hline $\begin{array}{l}\text { REGR factor } \\
\text { score } 4 \text { for } \\
\text { analysis } 2\end{array}$ & 147 & 0.70 & .155 & 2.093 & .038 & 1.000 & 1.000 \\
\hline
\end{tabular}

a. Dependent Variable: Consumer ethnocentrism.

Note. Calculated by the authors.

Heteroskedasticity testing was conducted using the White and Glejser tests in EViews. Based on the presented values of both tests, it could be concluded that the regression model was homoskedastic.

Table 7

Heteroskedasticity Test

Heteroskedasticity Test: White

Null hypothesis: Homoskedasticity

\begin{tabular}{lcll}
\hline F-statistic & 0.371468 & Prob. F(4,163) & 0.8287 \\
Obs*R-squared & 1.517616 & Prob. Chi-Square (4) & 0.8235 \\
Scaled explained SS & 0.943379 & Prob. Chi-Square (4) & 0.9183
\end{tabular}

\begin{tabular}{|c|c|c|c|}
\hline \multicolumn{4}{|c|}{$\begin{array}{l}\text { Heteroskedasticity Test: Glejser } \\
\text { Null hypothesis: Homoskedasticity }\end{array}$} \\
\hline F-statistic & 2.386429 & Prob. F(4,163) & 0.0533 \\
\hline Obs*R-squared & 9.294236 & Prob. Chi-Square (4) & 0.0542 \\
\hline Scaled explained SS & 7.598838 & Prob. Chi-Square (4) & 0.1074 \\
\hline
\end{tabular}

Note. Calculated by the authors. 


\section{Dragana Gašević, Marija Vranješ, Dragana Tomašević | 91}

\section{CONCLUSION}

The aim of the research conducted within this empirical study is to determine the key aspects of lifestyle of surveyed consumers that determine ethnocentric purchasing behavior. The results have shown that three out of the four factors that initially resulted from the use of factor analysis have a statistically significant effect on the consumer ethnocentrism of the respondents. These factors are: respondent's personality traits, rational and practical purchasing behavior and fashion awareness. The results of this study provide scientific input as they address the issue of by applying factor and regression analysis in the context of consumers from the Republic of Serbia. When it comes to managerial implications, the results are practically useful because they allow managers to create marketing strategies for the domestic market according to lifestyle factors that have the strongest impact on consumer ethnocentrism. A limitation of the research is that the hypothesis is only tested in a specific context, i.e. is only related to consumers from the territory of Novi Sad. In addition, the sample of respondents needs to be enlarged while it should be taken into account that the respondents from all categories are proportionally represented in the structure of the sample. Data on respondents from urban and rural areas should be entered in the questionnaire. Guidelines for researchers for the forecoming period may relate to the application of other statistical methods, such as cluster analysis, discriminant analysis, and the use of statistical methods for comparing groups.

\section{REFERENCES}

Acikdilli, G., Ziemnowicz, C., \& Bahhouth, V. (2018). Consumer ethnocentrism in Turkey: Ours are better than theirs. Journal of International Consumer Marketing, 30(1), 45-57.

Altinta, M. H., \& Tokol, T. (2007). Cultural openness and consumer ethnocentrism: an empirical analysis of Turkish consumers. Marketing Intelligence \& Planning, 25(4), 308 - 325.

Chendo, N. A. (2013). Ethnocentric tendencies and the buyer preferences in a developing South-East Nigeria. Global Journal of commerce \& management perspective, 2(3), 92-97.

Čutura, M. (2006). The impacts of ethnocentrism on consumers' evaluation processes and willingness to buy domestic vs. imported goods in the case of Bosnia and Herzegovina. South East European Journal of Economics and Business, 54-63. 
92 I THE INFLUENCE OF CONSUMER LIFESTYLE IN THE REPUBLIC OF SERBIA ON CONSUMER ETHNOCENTRISM

Garmatjuka, K., \& Partsb, O. (2015). Consumer ethnocentrism in Estonian skin care products market. Procedia - Social and Behavioral Sciences, 213, $610-615$.

Gašević, D., Jovičić, D. Tomašević, D. \& Vranješ, M. (2017). Primena faktorske analize u istraživanju potrošačkog etnocentrizma. Škola biznisa, $2,18-37$.

Homburg, C., \& Giering, A. (2001). Personal characteristics as moderators of the relationship between customer satisfaction and loyalty - an empirical analysis. Psychology \& Marketing, 18(1), 43-66.

Hsu, J. L. \& Nien, H-P. (2008). Who are ethnocentric? Examining consumer ethnocentrism in Chinese societies. Journal of Consumer of Behavior, $7(6), 436-447$.

Javalgi, R. G., Gross, A. C., Khare, V., \& Scherer, R. F. (2005). An application of the consumer ethnocentrism model to French consumers. International Business Review, 14(3), 325-344.

Josiassen, A., Assaf, A. G., \& Karpen, I. O. (2011). Consumer ethnocentrism and willingness to buy: Analyzing the role of three demographic consumer characteristics. International Marketing Review, 28(6), 627 646.

Jovetić, S. (2015). Merenje performansi preduzeća. Kragujevac: Ekonomski fakultet.

Kaynak, E., \& Kara, A. (1996). Consumer ethnocentrism in an emerging economy of Central Asia. In American Marketing Association Summer Educators' (pp. 514-520). San Diego.

Klein, J. G., Balaji, C. K., \& Ettenson, R. (2006). Extending the construct of consumer ethnocentrism: When foreign products are preferred. International Marketing Review, 23(3), 304-321.

Kucukemiroglu, O., Harcar, T., \& Spillan, John, E. (2006). Market segmentation by exploring buyer lifestyle dimensions and ethnocentrism among Vietnamese consumers: An empirical study. Journal of AsiaPacific Business, 7(4), 55-76.

Kucukemiroglu, O. (1999). Market segmentation by using consumer lifestyle dimensions and ethnocentrism: An empirical study. European Journal of Marketing, 33(5/6), $470-487$.

Kurnoga Živadinovic, N. (2004). Defining the basic product attributes using the factor analysis. Ekonomski pregled, 55(11-12), 952-966. 
Dragana Gašević, Marija Vranješ, Dragana Tomašević | 93

LeVine, R., \& Campbell, D. (1972). Ethnocentrism: Theories of Conflict, Ethnic Attitudes and Group Behaviour. New York: John Wiley and Sons Inc.

Mangnale, V. S., Potluri, R. M., \& Degfu, H. (2011) A study on ethnocentric tendencies of ethopian consumers. Asian Journa of business management, 3(4), 241-250.

Martínez, T. L., Barrio-García, S. Ibáñez-Zapata, J-A. (2000). Consumer ethnocentrism measurement - An assessment of reliability and validity of the CETSCALE in Spain. European Journal of Marketing, 34(11/12), 1353-1374.

Pallant, J. (2011). SPSS Priručnik za preživljavanje. Beograd: Mikro knjiga.

Pentz, C. D., Terblanche, N. S., \& Boshoff, C. (2014). Demographics and consumer ethnocentrism in a developing country context: a South Sfrican study. South African Journal of Economic \& Management Sciences, 17(4), 412-426.

Rojas-Mendez, J. I., Chaubey, M. D., \& Spillan, J. E. (2013). Consumer life styles and market segmentation in Chile. Journal of International Business Research, 12(2), 121- 140.

Sepehr, S., \& Kaffashpoor, A. (2012). Measuring the Ethnocentric Tendencies of Iranian Consumers: An Assessment of Validity and Reliability of the CETSCALE. Journal of International Consumer marketing, 22(4), 263274.

Sharma, S., Shimp, T.A., \& Shin, J. (1995). Consumer ethnocentrism: a test of antecedents and moderators. Journal of the Academy of Marketing Science, 23(1), 26-37.

Shimp, T. A., \& Sharma, S. (1987). Consumer ethnocentrism: construction and validation of the CETSCALE. Journal of Marketing Research, 24(3), 280-289.

Slišković, A., Zebić, I., Gregov, LJ., \& Nikolić, M. (2014). Uloga sociodemografskih karakteristika i životnog stila potrošača u određenju skolonosti kupovini. Tržište, 26(2), 227-244.

Spillan, J., Mayolo, C. A., \& Kucukemiroglu, O. (2007). Profiling Peruvian Consumers' Lifestyles, Market Segmentation, and Ethnocentrism. Latin American Business Review, 8(4), 38-59. 
94 | THE INFLUENCE OF CONSUMER LIFESTYLE IN THE REPUBLIC OF SERBIA ON CONSUMER ETHNOCENTRISM

Tai, S. H. C., \& Tam, J. L. M. (1998). A lifestyle analysis of female consumers in greater China. Psychology \& Marketing, 14(3), 287-307.

Teo, P.C., Mohamad, O. \& Ramayah, T. (2011). Testing the dimensionality of Consumer Ethnocentrism Scale (CETSCALE) among a young Malaysian consumer market segment. African Journal of Business Management, 5(7), 2805-2816.

Delivered: 12.06.2019. Accepted: 18.12.2019. 